\title{
ANALYSIS OF PHYSICO-CHEMICAL CHARACTERISTICS OF BANDAM KUNTA LAKE WATER FOR RESTORING AS A BIODIVERSITY HERITAGE SITE
}

\author{
P. Praveen Chari \\ Center for Water Resources \\ IST, JNTUH, Hyderabad, Telangana, India
}

\begin{abstract}
In this paper the Bandam Kunta lake which is recognized as Biodiversity Heritage Site (BHS) by National Biodiversity Authority (NBA). It is the first BHS in the state and for the first time in urban environment. The main objective of this paper is to evaluate physico chemical characteristics of this lake water and identifying the reasons for pollution of the lake and recommending some measures to restore it as a BHS. The study is carried out and the lake water parameters are analyzed for Pre Monsoon and Post Monsoon seasons. They include Pre Monsoon values are slightly increased than Post monsoon. This may be due to aeration of the lake during summer and concentration of the salts. The lake water is not suitable for drinking it can be used for agriculture. Reasons for degradation of lake water are identified as garbage dumping, idol immersion and fertilizers and pesticides usage in the catchment area. Due to presence of nitrates, phosphates and aquatic plant growth, fish living got deterioted due to anoxic condition and aesthetic look is displeasing. It is identified that lake is degraded and is leading to eutrophic conditions. Unnecessary aquatic plant growth that is mainly water lettuce can be controlled by mechanical means by raking or skimming. It is further recommended that by stopping garbage dumping, idol immersion and usage of fertilizers and pesticides, the problem can be solved.
\end{abstract}

Keywords - Bandam Kunta lake, Biodiversity Heritage Site and Physico-chemical characteristics

\section{INTRODUCTION}

On earth the distribution of water is extremely uneven. Only three percent of the water on the surface is fresh. The remaining ninety seven percent resides in the ocean as salt water. Of the fresh water sixty nine percent is in glaciers, thirty percent is underground, and less than one percent is located in lakes, rivers, streams and swamps. Of the fresh water available we have contaminated over eighty five percent by using our lakes, rivers and streams as a conduit for the

\author{
D. Vasantha Kumari \\ Center for Water Resources \\ IST, JNTUH, Hyderabad, Telangana, India
}

disposal of organic and chemical waste. A large portion of the population of the earth uses that contaminated water for drinking, cooking and cleaning. In Article 51A says it shall be the duty of every citizens of India ( $g$ ) To protect and improve the natural environment including forests, lakes, rivers and wildlife, and to have compassion for living creatures. 1.1 Description of the Study Area Government has taken responsibility to protect existing lakes by taking care through National biodiversity board and Telangana State Biodiversity Board. Giving the tag "Biodiversity Heritage Site" for the Bandam Kunta lake. It is eligible for locally constituted Biodiversity Management Committee funds for the protection and upkeep of the lake. Telangana government has chosen 13 lakes and given them the Title "Biodiversity Heritage site". Few lakes which are given Biodiversity Heritage sites are Mallanna Kunta (39.18 acres), Setty Kunta (17.18 acres), Kummari Kunta (11.28 acres), Kottha Kunta of area 7.39 acres and Bandam Kunta of area 7.38 acres. Among the thirteen lakes Bandam Kunta lake is selected for the Analysis of Physico-chemical characteristics of Bandam Kunta lake water for restoring it as a biodiversirty heritage site. Bandam Kunta lake is located in the Bandam kunta village, Ameenpur Mandal of Sangareddy district Telangana State -502 319. The details are show below.

Table 1.1 Details of Bandam Kunta Lake

\begin{tabular}{|c|c|}
\hline Latitude & $17^{\circ} 30^{\prime} 46^{\prime \prime}$ \\
\hline Longitude & $78^{\circ} 19.9^{\prime} 12^{\prime \prime}$ \\
\hline Lake Ayacut & $\mathbf{9 . 1 3}$ Acres \\
\hline Godavari Basin & Manjeera G4 group \\
\hline Capacity & $1.5 \mathrm{Mcft}$ \\
\hline Total Bund level & 101.20 \\
\hline Free board & $1.3 \mathrm{~m}$ \\
\hline Mean water level & 100.60 \\
\hline Full Tank Level & 100.00 \\
\hline Sill level & 98.50 \\
\hline Top width of bund & $3.0 \mathrm{~m}$ \\
\hline slopes inner & $11 / 2: 1$ \\
\hline Average depth & $1.2 \mathrm{~m}$ \\
\hline Bund length & $260 \mathrm{~m}$ \\
\hline
\end{tabular}




\begin{tabular}{|c|c|}
\hline Sluice is 1 no & @ Ch 2.00 \\
\hline Latitude & $17^{\circ} 30^{\prime} 46^{\prime \prime}$ \\
\hline Longitude & $78^{\circ} 19.9^{\prime} 12^{\prime \prime}$ \\
\hline Lake Ayacut & 9.13 Acres \\
\hline Godavari Basin & Manjeera G4 group \\
\hline Capacity & $1.5 \mathrm{Mcft}$ \\
\hline Total Bund level & 101.20 \\
\hline Free board & $1.3 \mathrm{~m}$ \\
\hline Mean water level & 100.60 \\
\hline Full Tank Level & 100.00 \\
\hline
\end{tabular}

Bandam Kunta lake is selected as Biodiversity Heritage site under G.O.Ms.No.70 on 15-11-2016 from Telangana state.

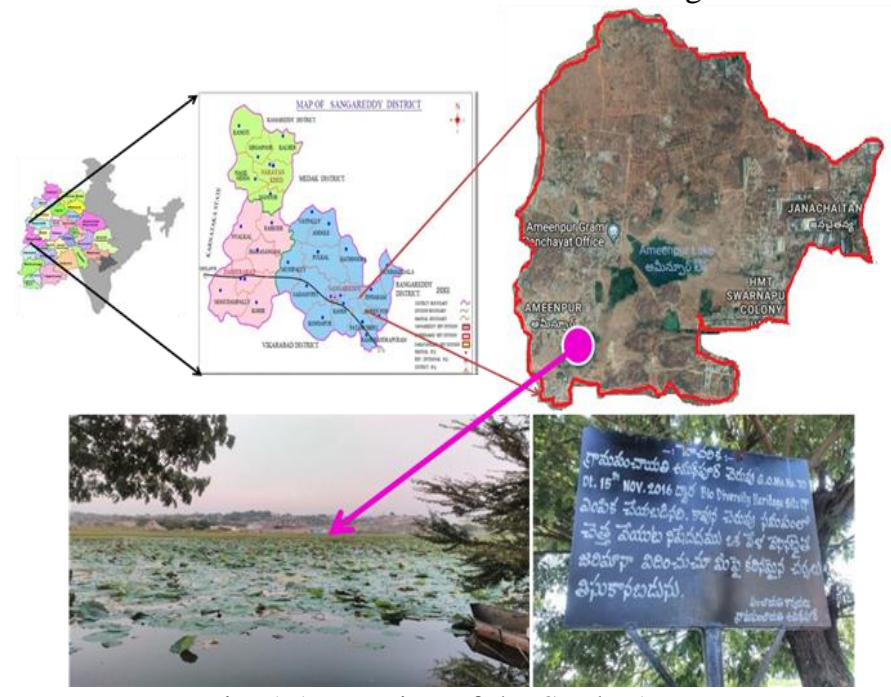

Fig. 1.1 Loaction of the Study Area

\subsection{Statement of the Problem}

In Hyderabad we have 3000 and above lakes and water bodies in 1970's.Now many lakes were disappeared or shrunk and now we have only few lakes remained. The existing lakes also are getting polluted by sewage mix, dumping of waste, industrial waste water and manmade activities. This water body purposes is to serve as drinking and irrigation source and includes fisheries. But above purposes are not served efficiently due to pollution of the lake by anthropogenic activities resulting in loss of scenic beauty of the lake some of the anthropogenic activities includes dumping of garbage throwing of plastic, immersion of idols, littering of thermacol, glass, fishing nets, aluminum cans. The main objective of this project is to show an overview of the Lake Situation and measures to protect the biodiversity around the lake.

\subsection{Objectives of the Project}

The present study is planned with the following objects.

1. To Analyze the physico-chemical Parameters of the lake water.

2. To identify the causes for degradation of the lake.

3. Measures for restoring the lake as a Biodiversity Heritage site

\section{LITERATURE REVIEW}

Irfan Rashid Sofi, Pallavi P. Chuchan (2017) have said that their study aims to find the residue and water purity of Lake Asan in the Uttarakhand. The Physico-chemical parameters of water are Alkalinity, PH, Temperature, EC, TDS, Total Hardness, Salinity, Potassium, Sodium, Nitrate, Phosphate, Chloride were analyzed and outcome has revealed that the lake is degraded and is going towards eutrophic phase. The contamination is due to adding of fertilizers, sewage pesticides, and other wastes.

Pramod N. Kamble, Viswas B. Gaikwad and Shashikant R (2011) has said that the aim of existing work is evaluation of physico chemical characteristics of water samples during the time of September to December 2008 from Bhandaradara reservoir. They noticed values of different physico-chemical characteristics of water samples which have been compared with standard values approved by WHO. Numerical studies calculated mean, standard deviation, co-variance and correlation coefficient between various pairs of characteristics. It is observed that the parameters observed have a positive and negative correlation with each other. However water from Bhandaradara reservoir is suitable for drinking purpose.

N. O. Eddy* and A. S. Ekop (2007) has said that the purity of water was tested after treatment by the Akwa Ibom State Water Company by collection water from various supply points for their physico-chemical characteristics such as major ions, bacteriological characteristics and nutrients for healthiness. The noticed values were compared with standard values approved by the World Health Organization for potable water. The healthiness of the evaluated water is proved fit for human consumption.

Rashmi Ranjan Mishra, Biswajit Rath , Hrudayanthnath Thatoi(2008) have investigated the Mangrove ecosystem which is appropriate for salty water shrimp culture. Huge number of aquaculture ponds have been cultured in the surrounding of Bhitarkanika National Park area of Orissa, India. These ponds are frequently given food by slightly salty water from close by Brahmani-Baitarani river network and the unchanged water is finally discharged into the mangrove ecosystem.

Sonam Shukla, D. K. Pandey, D. K. Mishra(2016) have studied the Physio-chemical characteristics of pond water and also Ground water in Rajnandgaon City in Chhattisgarh State. The research has been carried out to determine the appropriateness of the water for specific purposes. Water samples from major Ponds and major residential areas were collected during post-monsoon season for a physiochemical assessment. The research of physico-chemical nature of water samples indicates that the assessment of water quality healthiness as well as water quality management exercises should be worked out periodically to safe guard the water resources. 


\section{International Journal of Engineering Applied Sciences and Technology, 2019 \\ Vol. 4, Issue 1, ISSN No. 2455-2143, Pages 33-38 \\ Published Online May 2019 in IJEAST (http://www.ijeast.com)}

Sajitha V., Smitha Asok Vijayamma(2016) have studied in Athiyannoor panchayath, Thiruvananthapuram District, Kerala, about the quality of pond water through the physicochemical characteristics normally DO (Dissolved oxygen), EC (Electrical Conductivity), $\mathrm{Ca}$ (Calcium), $\mathrm{Cl}$ (Chloride), $\mathrm{Mg}$ (Magnesium), PH, K (Potassium), Nacl (Salinity), Na (Sodium), Temperature, TA (Total Alkalinity),TDS (Total Dissolved Solids), TH (Total Hardness). The results were evaluated and compared with WHO and BIS drinking water quality standards. From the values noticed, the water quality index was evaluated to quantify overall pond water quality position of the region.

\section{THEORITICAL BACKGROUND}

Water constitutes variety of unsettled, dissolved, suspended and bacteriological organisms. Some physical examination should be carried for testing of its physical characteristics such as temperature, color, odor, $\mathrm{PH}$, turbidity, Total Dissolved Solids etc, while chemical analysis should be executed for its Biochemical Oxygen Demand, Chemical Oxygen Demand, dissolved oxygen, alkalinity, hardness and other parameters.

\section{1 $\mathbf{P}^{\mathrm{H}}$}

$\mathrm{P}^{\mathrm{H}}$ is the acidity scale explains the medium of the sample. The negative logarithm of the concentration of hydrogen ion is $\mathrm{PH}$. PH measurement is also possible due to litmus paper of various $\mathrm{PH}$ papers. But the correct $\mathrm{PH}$ measurement is with $\mathrm{PH}$ meter. The PH value of water is defined as the $\log 10 / \mathrm{H}+$ (i.e., $\log$ of reciprocal of hydrogen ions present in the water).

\subsection{Electrical Conductivity}

Determination of conductivity is done by conductivity meter with dip-type cell. The instrument and cell are calibrated by using $0.0005 \mathrm{M} \mathrm{KCl}$ solution having conductivity $654 \mu$ Mho cm-1. To carry a electricity a solution should requires charged ions or particles. Nearly conductivity estimations are made in hydrous solutions, and the ions accountable for the conductivity come from electrolytes dissolved in the water. Conductivity is a characteristic by virtue of the current passed through water or a solution.

\subsection{Total Dissolved Solids (TDS)}

Total dissolved solids expressed as the substance remained in the vessel after removal of moisture of a sample of water and waste water and it is achieved by heating in a hot oven at a specified temperature. The Total dissolved solids comprise of total suspended solids and dissolved solids. TDS originate from runoff, Natural sources, chemicals and industrial wastes used in wastewater treatment plants

\subsection{Sodium}

By using flame photometer sodium can be estimated at 589 $\mathrm{nm}$. The device is standardized with the known accumulation of sodium ion (1 to $100 \mathrm{mg} / \mathrm{l}$ ). The samples having increased accumulation are appropriately diluted with distilled water and the dilution factor is applied to the noticed values. When sample is examined in flame it reflects light nature and comes to excitation condition. At $589 \mathrm{~nm}$ accumulation of sodium and light intensity are proportional, by using light dispersion devices it can be read.

\subsection{Potassium}

Potassium is examined with the device flame photometer. The device is standardized with known accumulation of potassium solution, and in the value range of $1 \mathrm{mg}$ to $5 \mathrm{mg} / \mathrm{l}$. The sample having higher accumulation is appropriately diluted with distilled water and the dilution factor is applied to the noticed values. Potassium is a vital element present in all plant and animal tissues.

\subsection{Calcium}

PH conditions should be more than 12.0, Reeder's and Patton's indicator is utilized then calcium is examined by complex metric titration with EDTA standard solution. These processes are accomplished by adding a fixed volume of $4 \mathrm{~N}$ Sodium Hydroxide. The concentration of calcium in the sample is given by volume of titre (EDTA solution) against the known volume of sample.

\subsection{Magnesium}

Like calcium magnesium is also found in all natural waters and its sources are from rocks. It usually exists in accumulations lower than those of calcium. Magnesium is a essential element of chlorophyll. Its huge content decreases the usage of water for specific use. A concentration above 500 $\mathrm{mg} / \mathrm{l}$ conveys a disagreeable taste and the water unsafe for drinking purposes.

\subsection{Alkalinity}

Alkalinity is Composed basically of carbonates (CO3 2- ) and bicarbonates (HCO3-), It acts as a balance for $\mathrm{PH}$. Alkalinity, $\mathrm{PH}$ and hardness influence the poisonous of numerous materials in the water. The presence of hydroxyl and carbonate ions results overall alkalinity in boiler water. To safeguard the boiler against rust Hydroxyl alkalinity (causticity) is essential in boiler water. Operating troubles, such as foaming occurs due to too high a causticity.

\subsection{Chlorides}

To determine chlorides, Argentometric Method and particularly Mhos method. is used When Potassium Chromate indicator is added to chloride solution and titre against silver nitrate there will be formation of brick red color at the end point which is silver chromate.

\subsection{Sulfates}

Sulfate from water sample is precipitated as Barium Sulfate in the acidic medium. Precipitate washed, dried and measured as BaSO4. 


\section{International Journal of Engineering Applied Sciences and Technology, 2019 \\ Vol. 4, Issue 1, ISSN No. 2455-2143, Pages 33-38 \\ Published Online May 2019 in IJEAST (http://www.ijeast.com)}

\subsection{Nitrates}

Nitrate when reacts with brucine produces yellow colour is the presence of $\mathrm{H} 2 \mathrm{SO} 4$ this can be measured spectrophotometrically at $410 \mathrm{~nm}$.

\subsection{Fluorides}

A fluoride concentration of approximately $1.0 \mathrm{mg} / \mathrm{l}$ in drinking water effectively decreases dental caries without harmful effects on health. Fluoride may genesis normally in water or it may be added in managed amounts. Some fluorosis may cause when the fluoride level increases above the recommended range. In rare instances the normally occurring fluoride accumulation may reach $10 \mathrm{mg} / \mathrm{l}$; such water should be defluoridated.

\subsection{Total Hardness}

Ethylene diamine tetra acetic acid (EDTA) and its sodium salt form a chelated soluble complex when added to a solution of certain metal cations. Addition of little quantity of a dye such as Erichrome Black $\mathrm{T}$ to an aqueous solution of magnesium and calcium ions of PH 10.0, changes the solution wine red. The calcium and magnesium becomes complicated and the color of the solution changes to blue from wine red, when EDTA is added as titrant, marking the finishing point of the titration. This on calculating using the formula gives the total hardness.

\subsection{Phosphates}

Organic phosphorus is converted to orthophosphates by heating or by sulfate digestion while inorganic phosphates are converted to orthophosphates by $\mathrm{H} 2 \mathrm{SO} 4$ digestion. The phosphates thus released can be determined calorometrically.

\subsection{Chemical Oxygen Demand}

Assessment of the quantity of matter that can be consumed in the existence of a strong chemical oxidizing agent is known as Chemical Oxygen Demand. Since the COD examination can be executed frequently, it is again and again utilized as an uneven approximation of the water's BOD, even though the COD examination evaluates some additional organic matter does not naturally oxidized by biological reaction. As with the BOD test, the COD test is results as $\mathrm{mg} / \mathrm{l}$ of oxygen utilized.

\subsection{Biochemical Oxygen Demand}

Biochemical Oxygen Demand is the estimation of pollutant organic matter existing in the water sample, and can be explained as the quantity of oxygen necessary by the microorganisms in balancing the biological pollutant organic material under aerobic phase. The principle of the method involves, evaluating the difference of the oxygen accumulation between the sample and after incubating it for 5 days at $20^{\circ} \mathrm{C}$.

\section{IV.METHODOLOGY, RESULTS AND DISCUSSIONS}

\subsection{Sampling of Water}

Water samples are collected by proper method, such that it doesn't involve any external contamination. Samples are collected at 10 different locations in and around the lake at 1-2 $\mathrm{m}$ depth. Bottles are cleaned by good quality detergent and washed with $\mathrm{H} 2 \mathrm{SO} 4$, then boiled and stopper was fixed.

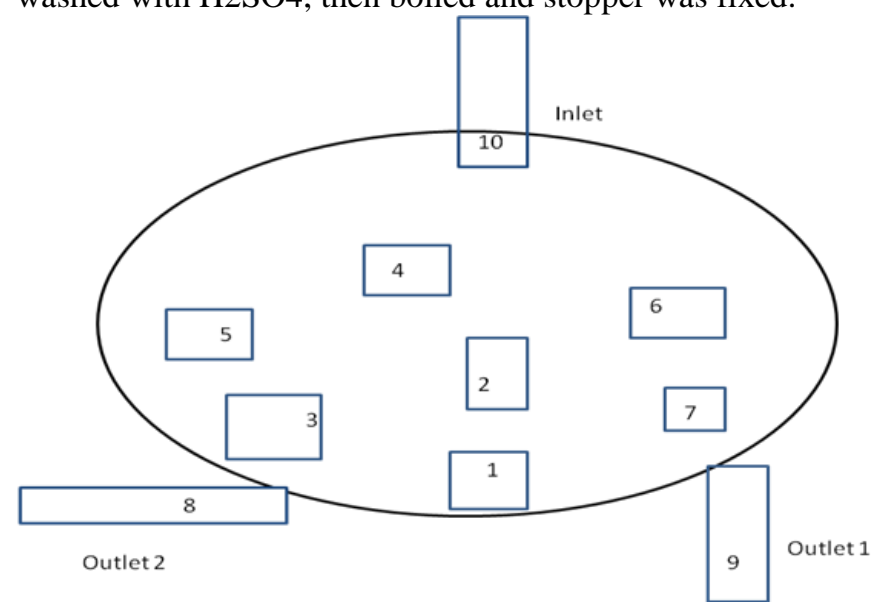

Fig. 4.1.Collection points of water sample in the lake

\subsection{Sample collection}

Polythene bottles are used to collect water samples. The bottles are initially washed with fresh water and soap. After that the bottles are washed with lake water before collecting samples from the lake. First the bottle was dipped in the water with closed cap at the depth of $15 \mathrm{~cm}$ to $30 \mathrm{~cm}$. Then water is collected by opening the cap of the bottle and brings up the bottle after closing the cap.

\subsection{Sample Handling and Preservation}

After collection of water samples from the lake it is immediately analysed for the physical and chemical properties. Few parameters like Total Dissolved solids, PH, DO, Electrical conductivity are to be analysed before the quality of the water changes. Preservation of collected samples are done by adding chemicals.

- For analyzing $\mathrm{pH}$, the sample is collected in a polythene container and should be measured within four hours of sample collection.

- For analyzing DO and COD the sample is collected in a polythene con-tainer and it is preserved by adding $\mathrm{H} 2 \mathrm{SO} 4$ and refrigerate.

- For analyzing Nitrates the sample is collected in a polythene container and it is preserved by adding $\mathrm{HgCl} 2$ and refrigerate. - For analyzing Sulfides the sample is collected in a polythene container and it is preserved by adding $2 \mathrm{~N} \mathrm{Zn}$ (CH3COO) 2 and $1 \mathrm{M} \mathrm{NaOH}$ stir and refrigerate.

- For analyzing Phosphates the sample is collected in a polythene container and it is preserved by adding $\mathrm{HgCl} 2$ stir and refrigerate.

- From the Fig 5.1 it can be found that is the lake location and various points selected for sample collections. The water is tested for the Inlet, center point and two outlets of the lake.10 
No. Samples are taken from the lake during Pre Monsoon and Post Monsoon seasons and tested for different physical and chemical properties.

\section{TABLE 1.2 PRE MONSOON \& POST MONSOON} RESULTS

\begin{tabular}{|c|c|c|c|}
\hline Parameter & $\begin{array}{c}\text { Average of } \\
\text { Pre- } \\
\text { Monsoon } \\
\text { Values }\end{array}$ & $\begin{array}{c}\text { Average of } \\
\text { Post- } \\
\text { Monsoon } \\
\text { Values }\end{array}$ & BIS Standards \\
\hline $\mathrm{p}^{\mathrm{H}}$ & 7.41 & 7.51 & $6.5-8.5$ \\
\hline $\mathrm{EC}$ & 1227 & 993.1 & $750-2250 \mu \mathrm{sie} / \mathrm{cm}$ \\
\hline TDS & 785.3 & 635.6 & $500-2000 \mathrm{mg} / \mathrm{l}$ \\
\hline Sodium & 147.9 & 108.2 & $<200 \mathrm{mg} / \mathrm{l}(\mathrm{WHO})$ \\
\hline Potassium & 3.1 & 8.2 & $<10 \mathrm{mg} / \mathrm{l}(\mathrm{WHO})$ \\
\hline Calcium & 66.4 & 50.4 & $75-200 \mathrm{mg} / \mathrm{l}$ \\
\hline Magnesium & 30.9 & 31.6 & $30-100 \mathrm{mg} / \mathrm{l}$ \\
\hline Alkalinity & 264.5 & 247.4 & $200-600 \mathrm{mg} / \mathrm{l}$ \\
\hline Chlorides & 238 & 163 & $250-1000 \mathrm{mg} / \mathrm{l}$ \\
\hline Sulfates & 3.1 & 8.4 & $200-400 \mathrm{mg} / \mathrm{l}$ \\
\hline Nitrates & 1.53 & 6.8 & $0.1(\mathrm{Surface} \mathrm{water})$ \\
\hline Fluorides & 0.91 & 0.92 & $1.0-1.5 \mathrm{mg} / \mathrm{l}$ \\
\hline TH & 294 & 256 & $200-600 \mathrm{mg} / \mathrm{l}$ \\
\hline Phosphates & 0.2 & 0.48 & $<0.1(\mathrm{US} \mathrm{EPA})$ \\
\hline COD & 78 & 66 & $10 \mathrm{mg} / \mathrm{l}$ \\
\hline BOD & 23.44 & 16.82 & $5 \mathrm{mg} / \mathrm{l}$ \\
\hline
\end{tabular}

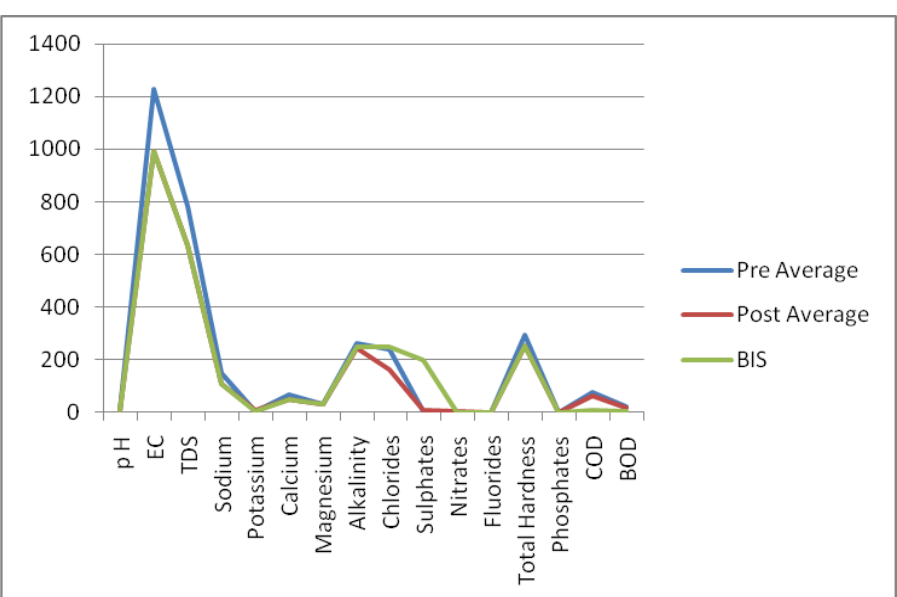

Fig 4.2 Comparison of Standard with average of Post and Pre Monsoon Values

\subsection{OBSERVATIONS FROM THE RESULTS.}

$\checkmark \quad$ From the Table 1.2 and Fig. 4.2, values of Pre Monsoon are slightly increased than Post monsoon. This may be due to aeration of the lake during summer and concentration of the salts.

$\checkmark$ Some of the parameters like $\mathrm{pH}$, Electrical conductivity, Total dissolved solids, Magnesium, Alkalinity, Total Hardness are as per BIS limits and Sodium \& Potassium are as per WHO limits. $\checkmark$ Some of the parameters like Calcium, Chlorides, Sulfates, and Fluorides are having lower values than BIS standards.

$\checkmark \quad$ Some of the parameters like Nitrates, Phosphates, Chemical oxygen Demand and Biochemical oxygen Demand values are having higher values than standards. Hence lake water is under deteriorating conditions leading to Eutrophication.

\section{CONCLUSIONS}

1. The $\mathrm{pH}$, Electrical conductivity, Total dissolved solids, Magnesium, Alkalinity Total Hardness in the lake are within the permissible limit.

2. Nitrates, Phosphates, Chemical Oxygen Demand and Biological Oxygen Demand (BOD) concentrations are very high in the lake which leads to several problems in both human and plants if water is used for their purposes. It increases the rate of biomass and growth of algae and weeds in the lake water. As a result, the lake is nearer to the Eutrophication stage. As the Chemical Oxygen demand (COD) and Biological Oxygen demand (BOD) concentrations are higher in concentrations this water cannot be used for drinking. Due to higher COD and BOD concentrations there is a gradual decrease in dissolved oxygen which causes the suffocative conditions for aqua culture living in the lake.

3. Calcium, Chlorides, Sulfates, Nitrates and Fluorides are very low compared to the standards.

By taking the above considerations into account, it is evident that the water of the Bandam kunta lake is unfit for drinking and can be used for irrigation after minimal treatment.

\section{RECOMMENDATIONS}

- The soil is also an important factor which is responsible in changing the characteristics of lake water; hence soil investigations are to be done around the lake for better results. - Biodiversity around the lake and nearby places can be extended for further studies. - The present study is restricted to ten samples only, the collection of number of samples can be extended for better results. - The research can be extended to few more seasons or years to know the complete quality of lake.

- Concerns for improving health of the lake have been expressed and conceptual strategies for rejuvenation, conservation and management of Bandam Kunta Lake have been suggested.

\section{ACKNOWLEDGEMENT}

I take this opportunity to express my heartfelt thanks and long felt sense of gratitude to my guide Prof. B. VENKATESWARA RAO, Professor of Water Resources and Director Institute of Science and Technology, Jawaharlal Nehru Technological University Hyderabad for his excellent guidance in executing this project. 


\section{International Journal of Engineering Applied Sciences and Technology, 2019 \\ Vol. 4, Issue 1, ISSN No. 2455-2143, Pages 33-38 \\ Published Online May 2019 in IJEAST (http://www.ijeast.com)}

I express my hearty gratitude to my parents for giving me the freedom and opportunity to pursue my own interests.

\section{REFERENCES}

[1] Irfan Rashid Sofi, Pallavi P. Chuchan (2018), “ Assessment of Physico-Chemical Properties of Water and Sediments of Asan Lake Dehradun, India" International Journal of Theoretical \& Applied Science Vol. 10, No.1 (pp:68-76).

[2] Pramod N. Kamble, Viswas B. Gaikwad and Shashikant R (2011), "Monitoring of Physico Chemical Parameters and Quality Assessment of Water from Bhandaradara Reservoir" Pelagia Research Library, Der Chemica Sinica, Vol. 2, No.4 (pp:229-234).

[3] N. O. Eddy* and A. S. Ekop (2007), "Assessment of the Quality of Water Treated and Distributed By the Akwa Ibom State Water Company" ISSN: 0973-4945; CODEN ECJHAO E-Journal of Chemistry, Vol. 4, No. 2, (pp 180186).

[4] Rashmi Ranjan Mishra, Biswajit Rath , Hrudayanthnath Thatoi (2008), "Water Quality Assessment of Aquaculture Ponds Located in Bhitarkanika Mangrove Ecosystem, Orissa, India" Turkish Journal of Fisheries and Aquatic Sciences Vol. 8, (pp:71-77).

[5] Rizwan Reza and Gurdeep Singh (2010), "Application of water quality index for assessment of pond water quality status in Orissa, India" Current World Environment An International Research Journal of Environmental Science, Vol. 5 No.2, (pp:305-310).

[6] Sonam Shukla, D. K. Pandey, D. K. Mishra (2016), "Assessment of Ground and Pond Water Quality of Rajnandgaon City, Chhattisgarh, India" International Journal of Advanced Research in Science, Engineering and Technology, Vol. 3, Issue 1, January 2016.

[7] Prabal Chatterjee and Braj Kishor Prasad Singh(2015), "Water quality assessment of a perennial pond of Muzaffarpur (Bihar -India)" International Journal of Education \& Applied Sciences Research, Vol.2, Issue 5, (pp 08-16).
[8] Sajitha V., Smitha Asok Vijayamma (2016), "Study of Physico-Chemical Parameters and Pond Water Quality Assessment by using Water Quality Index at Athiyannoor Panchayath, Kerala, India" Emer Life Sci Res, Vol. 2 No.1 (pp: 46-51).

[9] Patil. P.N, Sawant. D.V, Deshmukh. R.N (2012), "Physico-chemical parameters for testing of water - A review" International Journal of Environmental sciences Vol. 3, No.3, (pp:1194-1207).

[10] Hemlata Mahobe et.al (2013) “ Study of PhysicoChemical Characteristics of Water Ponds of Rajnandgaon Town, Chhattisgarh International Journal of Scientific \& Engineering Research, Vol 4, Issue 8, August-2013; ISSN 2229-5518.

[11] Medona Mary et.al (2014) "Evaluation of Physical and Chemical characteristics of Water at Sothuparai reservoir, Theni District, Tamilnadu, India" International Research Journal of Environment Sciences; ISSN 2319-1414, Vol. 3(8), (pp: 36-39).

[12] Purushottam J. Puri et.al (2010) "Study and Interpretation of Physico-Chemical Characteristic of Lake Water Quality in Nagpur city (India)" Rasayan Journal of Chemistry; Vol.3, No.4 (2010), ISSN 800-810; 09741496; CODEN: RJCABP.

[13] Suman Tanwar et.al (2014) "Assessment of Physicochemical Characteristics of Receational Lake Tilyar, Rohtak (Haryana) India." International Journal of Pure Applied. Bioscience; ISSN: 2320 - 7051, Vol 2 (2); (pp: 204-212)

[14] Saurabh Mishra, M.P. Sharma and Amit kumar (2015), "Assessment of Water Quality in Surha Lake Based on Physiochemical Parameters, India". Journal of Materials and Environmental Science; ISSN: 2028-2500; CODEN: JMESC, vol 6 (9) (pp: 2446-2452). 